\title{
Analisis y composicion geometrica del frente norte de la capilla de San Miguel, la seo de Zaragoza
}

\author{
Javier Peña Gonzalvo \\ Luis Agustín Hernández
}

\section{Abstract}

En el trabajo de investigación, enmarcado dentro del campo del Patrimonio Arquitectónico, utilizando la tecnología del escáner-laser y la fotogrametría terrestre y aérea de baja cota, se ha realizado un levantamiento de la fachada noreste de la capilla de San Miguel, conocida localmente como la Parroquieta, para obtener una ortofotografia y estudiar la decoración geométrica de dicho muro, que algunos autores califican como mudéjar, construida por maestros de origen musulmán que vivían en el territorio cristiano tras la conquista de Saraqusta y otros como arquitectura islámica, donde dicho muro habría pertenecido a la antigua mezquita aljama de Saraqusta.

En el trabajo se describe la actual Capilla de San Miguel y se relaciona con la mezquita, centrando el tema del trabajo en el muro noreste, haciendo una descripción pormenorizada de la misma haciendo referencia a los últimos hallazgos sobre inscripciones, un análisis geométrico pormenorizado, donde se llega a la conclusión de que los ventanales góticos, obedecen a una geometría diferente de la composición geométrica de cerámica y ladrillo, e interrumpen en sus módulos y continuidad, alterándolos. También se relaciona con decoración de la arquitectura islámica de oriente, esencialmente la Abasí, ya que los hechos históricos relacionan ambas partes del Califato hasta la escisión de Al-Andalus, para finalmente contextualizarla con dos edificios cercanos de su entorno, el palacio de la Aljafería y el monasterio de Sijena.

\section{Palabra clave}

decoración geométrica, arquitectura Zagrí, Parroquieta, arquitectura Saraqusta.

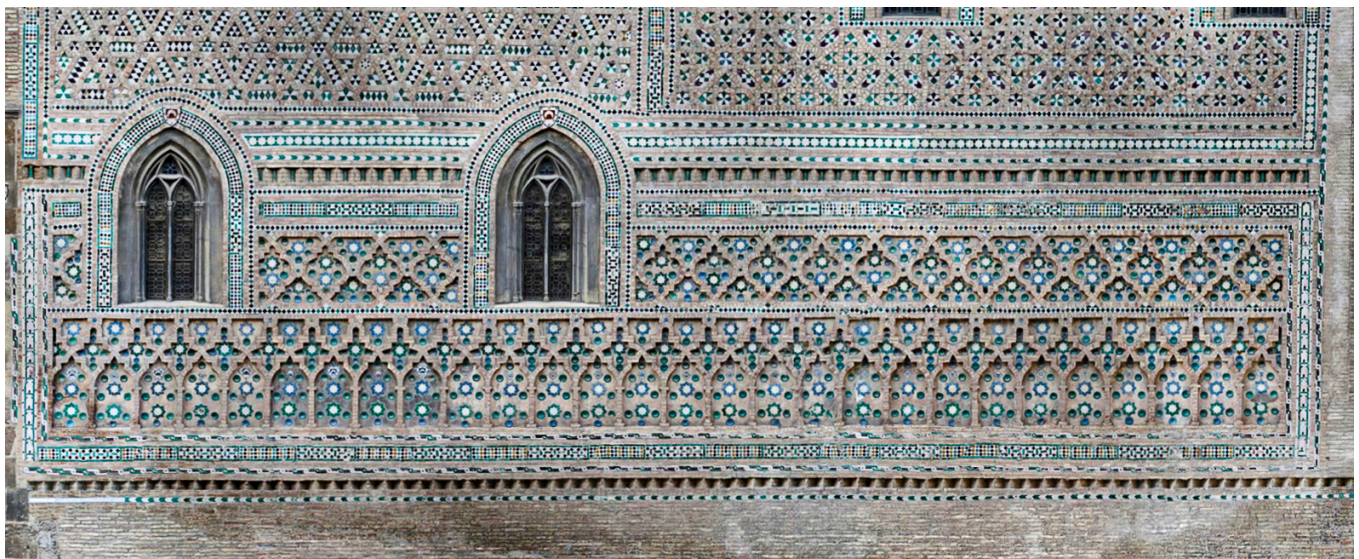




\section{Introducción}

La Parroquieta es el nombre que recibe popularmente la capilla de San Miguel, en la catedral de Zaragoza o Seo del Salvador, erigida hacia I 380 por el arzobispo don Lop Ferrench de Luna para albergar su sepultura. La Seo se asentó en I I 2 I, tras la conquista aragonesa de Saraqusta, en la mezquita aljama, y no es hasta finales del s. XII, cuando empieza su transformación al adosarle tres ábsides románicos que han llegado hasta la actualidad, habilitando una parte de la extensa mezquita para el uso cristiano. En el s. XIV prosigue la progresiva sustitución del antiguo edificio islámico por otro gótico, una iglesia de tres naves alineadas con los ábsides. En el s. XVI culmina su transformación, con su singular planta cuadrada, al ampliarse a lo ancho y largo hasta alcanzar los antiguos cerramientos de la mezquita, pero manteniendo todavía alguno de sus elementos, como el alminar nuevo envuelto en el campanario barroco, o el muro NE y posiblemente la cúpula de madera de la Parroquieta.

\section{El Edificio}

Se trata de un edificio adosado por el SE al ábside del Evangelio, y por el SO a la nave del crucero, siendo exterior por los otros dos lados. Con unas dimensiones aproximadas de $22,50 \times 10,00 \mathrm{~m}$ y una altura de 17,00 m hasta el mirador que remata el edificio, tiene una nave de dos tramos cubiertos por bóvedas de crucería (figg. I, 2), trabajadas en piedra, algo excepcional en la ciudad de Zaragoza, y un presbiterio de planta cuadrada, cubierto por una cúpula de madera decorada con mocárabes y epigrafía árabe; en un arcosolio se ubica el sarcófago gótico que contiene los restos del arzobispo. Los cerramientos son muros de doble hoja que albergan escaleras y corredores, cubiertos por bovedillas enjarjadas de ladrillo que a su vez traban la hoja exterior con la interior, lo que evita la construcción de contrafuertes.

Como en muchos otros edificios medievales, la datación en el s. XIX de la Parroquieta se ha venido efectuando tradicionalmente en base a fuentes parciales o circunstanciales, en este caso por la intervención puntual de un maestro de obras, dos azulejeros sevillanos y un escultor catalán, lo que no puede ser concluyente. No se han tenido en cuenta, en cambio, aspectos relevantes que pueden indicar la reutilización de un edificio anterior, como la violenta irrupción de las 4 ventanas góticas en una fachada dotada de una extensa y depurada

Fig. I. Ubicación, Foro Romano en amarillo, con el templo, patio de la mezquita en verde, capilla de San Miguel en naranja. Fuente dibujo del autor.

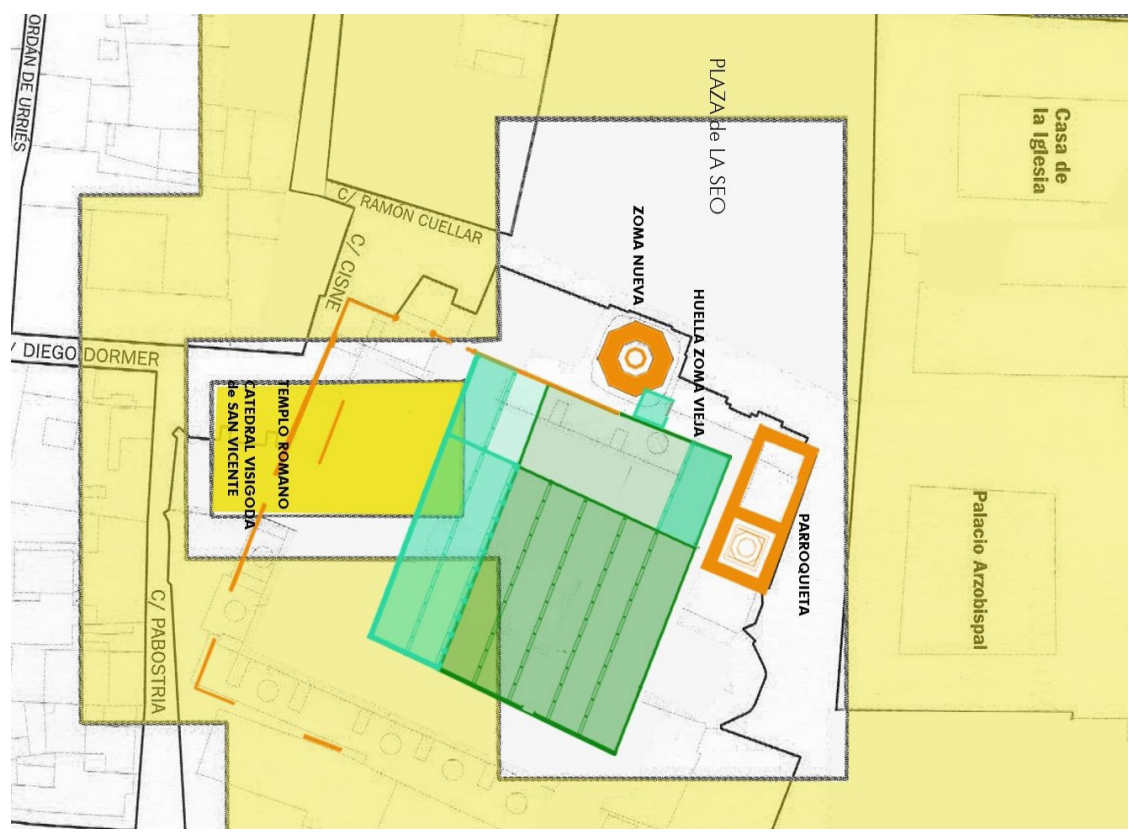


decoración geométrica, la falta de sintonía estructural y constructiva entre el exterior, de ladrillo y el interior, de piedra sillar, y la singularísima decoración de la cúpula de madera del presbiterio, decorada con mocárabes y con "una larguísima inscripción de compleja escritura cufí, de unos 40 metros lineales" [Sanmiguel, Agustín 2002, p. 254], aunque otros investigadores la relacionan con el arte nazarí [Cabañero Subiza, Bernabé and Lasa Gracia, Carmelo 2004]. En 1992, se halló una nueva y precisa fuente documental, una inscripción en árabe cúfico: بل "la obra es de Salāma bn Gālib", fechable en el s. XI [Martinez-Enamorado, Peña-Gonzalvo 2016, p. II3].

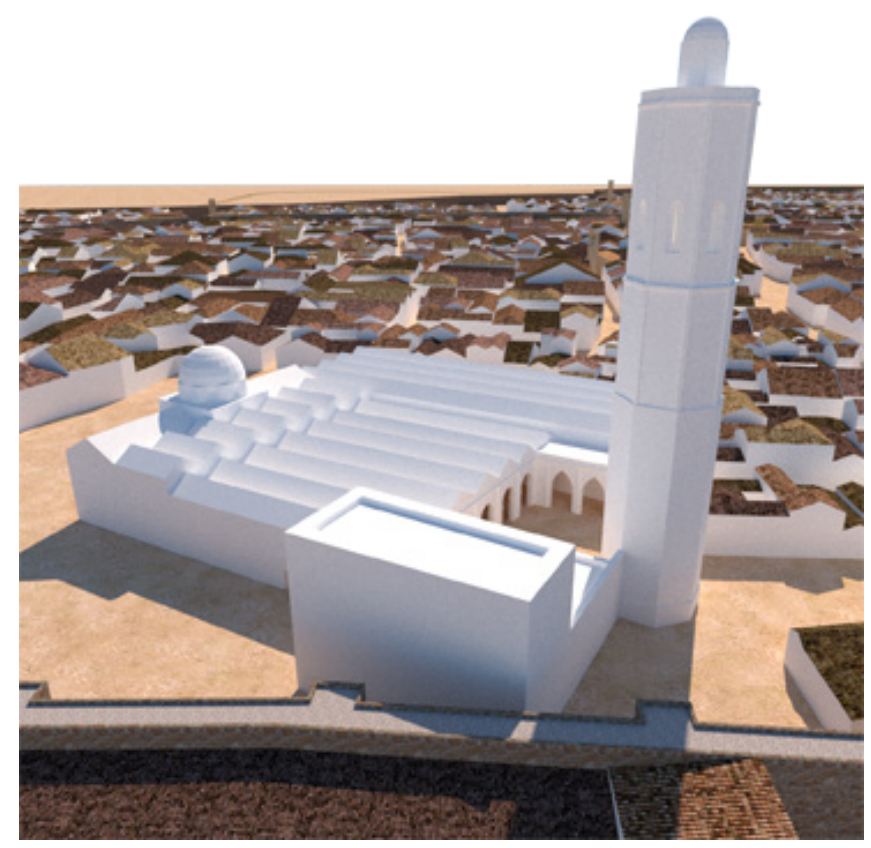

\section{La decoración geométrica en la arquitectura islamica}

La primera arquitectura islámica, la de época omeya, representada por las mezquitas de la Cúpula de la Roca de Jerusalén (69|-692) y la mezquita aljama de Damasco (706-7|4), "corresponde(n) en todos sus detalles a las formas habituales del arte cristiano de Siria y Palestina" [Enderlein, Volkmar 2007, p. 65]. En 749, los Abasíes arrebatan el poder a los Omeyas, trasladando su residencia a Iraq y en 762 al-Mansur construye la nueva capital, Bagdad, en un medio geográfico donde el ladrillo y el estuco estaban asentados antes del islam, por lo que fue adoptado.

La decoración mediante figuras geométricas aparece ya en el castillo de Uxaydir (775), y combinada con decoración vegetal se conserva en los edificios más antiguos de Samarra, la nueva capital abasí entre 835 y 892. El orden geométrico se convirtió en la norma del arte islámico, que quiso evitar imágenes, pero que a pesar de ello deseaba satisfacer las necesidades de toda cultura de poder repetir sus mejores creaciones" [Grabar 2007, p. 49]. En el NE iraní, tras la llegada al poder de dinastías locales, aparecen los ejemplos más antiguos conservados, donde el ladrillo y el yeso permiten que la geometría sea el principal soporte decorativo. Según la caracterización de los estilos arquitectónicos iraníes islámicos hasta el s. XIII [Pirnia 2003], el estilo Jorasaní es el primero que aparece, muy influenciado por la arquitectura preislámica, como la mezquita de Na'in, s. X. El segundo estilo es el Razí, que abarca tres ramas, la Samaní, con el mausoleo de Isma'il (892-907), Bujará (fig. 3); la Ziyarí, con la torre-mausoleo de Gonbad-e Kavus ( | 006- |007), o la portada de la mezquita de Jurjir (976-985) en Isfahán; y la Selyuquí, que desde mediados del s. Xl, emplea magistralmente el ladrillo dispuesto con lacerías geométricas más complejas: "El ladrillo, normalmente cuadrado y combinado de distintos modos ... se utilizaba tanto para la construcción 
Fig. 3. Mausoleo Ismail Samani. Bajará. Fuente: internet libre de derechos de autor

Fig. 4. Palacio de la Aljafería. Zaragoza. Fuente fotografía del autor.
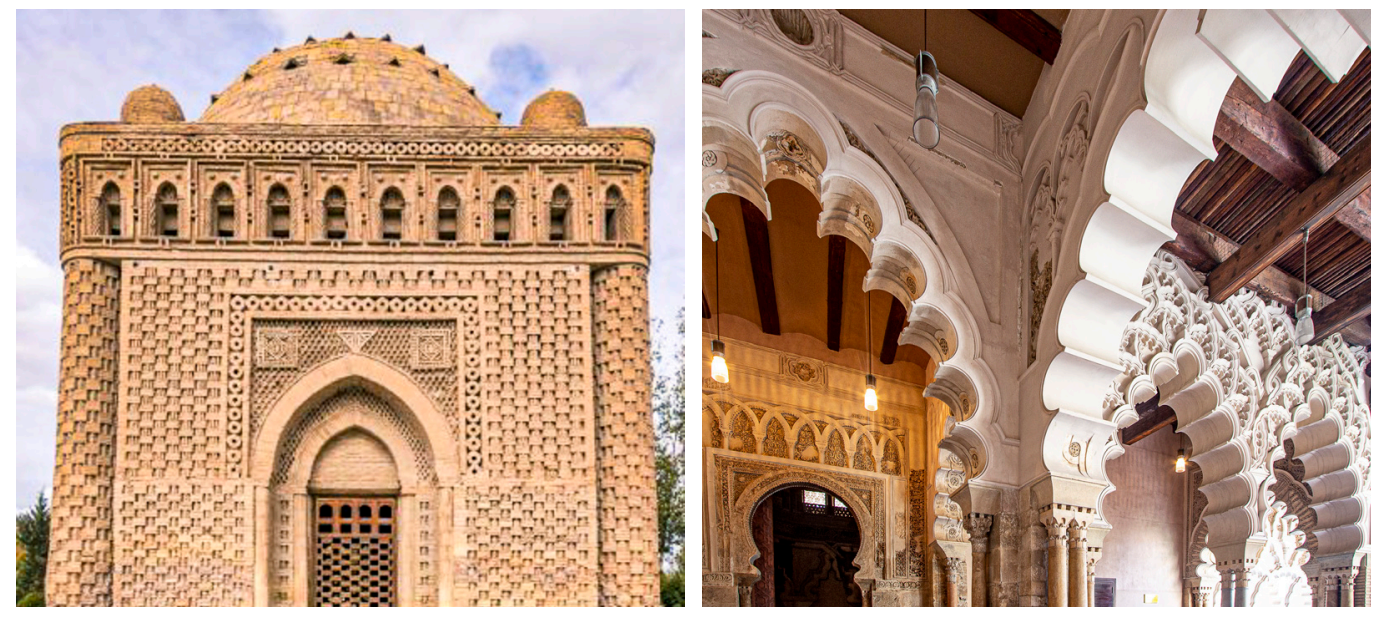

como para la decoración ... con loza de distintos colores -unas bandas de color turquesa, piedras ornamentales de color azul oscuro, blancas y verdes, enriquecían el ocre del edificio" [Chmelnizkij, Sergej 2007, p. 354]. Mezquitas, alminares, mausoleos, caravansares y todo tipo de edificios públicos, presentan soluciones decorativas geométricas, tales como estrellas de seis, de ocho puntas, enlazadas o no, rombos, cadenas, cruces, etc. muchos de ellos presentes también en la arquitectura "mudéjar" aragonesa.

En cuanto a la cerámica vidriada, "el uso de azulejos empezó en el arte islámico en el siglo IX, estos azulejos de lustre (de Kairuán), adornados en diferentes tonos verdes, marrones y amarillos, fueron probablemente importados de Irak ... (dispuestos) en un modelo romboidal para doblar la superficie decorada. A finales del siglo XI se formó en el norte de África la técnica de juntar azulejos convirtiéndolos en un modelo geométrico ... en la segunda mitad del siglo XII se utilizaron bandas y paneles de azulejos para adornar los alminares almohades de Marruecos y Andalucía. En los países islámicos orientales, la utilización de la decoración de azulejos tomó otro rumbo a partir del siglo Xl... empezaron a experimentar con elementos esmaltados de color turquesa, pero enseguida se añadieron otros colores como el blanco y el azul cobalto y las superficies decoradas con azulejos fueron ganando tamaño" [Blair, Sheila and Bloom, Jonathan 2007, p. 448].

La fuerte personalidad de la cultura abasí también se dejó notar en Al-andalús, y así, la ampliación de Alhaquén II de la mezquita de Córdoba (962-966) incorpora elementos de aquella, especialmente la geometría en la decoración en las bóvedas nervadas situadas en la maqsura y en la nave central ampliada, que también incorporan los arcos lobulados y entrecruzados. Estos elementos también se conservan en la pequeña mezquita de Bíb Mardúm, Toledo (999/1000). El palacio de la Aljafería de Zaragoza, segunda mitad del s. $\mathrm{Xl}$, desarrollará estos elementos geométricos e incorporará otros nuevos como los arcos mixtilíneos (fig. 4).

\section{El muro noreste}

El gran paño rectangular que ocupa la mayor parte de la fachada NE (fig. 5) consta de tres cuerpos separados por sendas bandas de esquinillas, la central y la superior decoradas con columnitas vidriadas verdes, y a su vez, cada una de ellas, enmarcada con una estrecha orla decorada con azulejos, generalmente blancos y verdes en punta de flecha, y otras más anchas decoradas con cerámica vidriada de pequeños azulejos cuadrados (en losange) y rectangulares de colores melado, blanco, verde y morado-negruzco. Mientras que el cuerpo inferior tiene su interior rehundido y enlucido, decorado con azulejos de tres tipos: estrellas blancas de 8 puntas ribeteadas con azulejos verdes o azules, platos de cerámica verde y baldosines blancos dispuestos en losange con las armas de los Ferrench de Luna, en los 
Fig. 5. Ortofotografía muro noreste. Fuente investigación de los autores.

Fig. 6. Detalle donde se observa la citada inscripción. Fuente imagen del autor
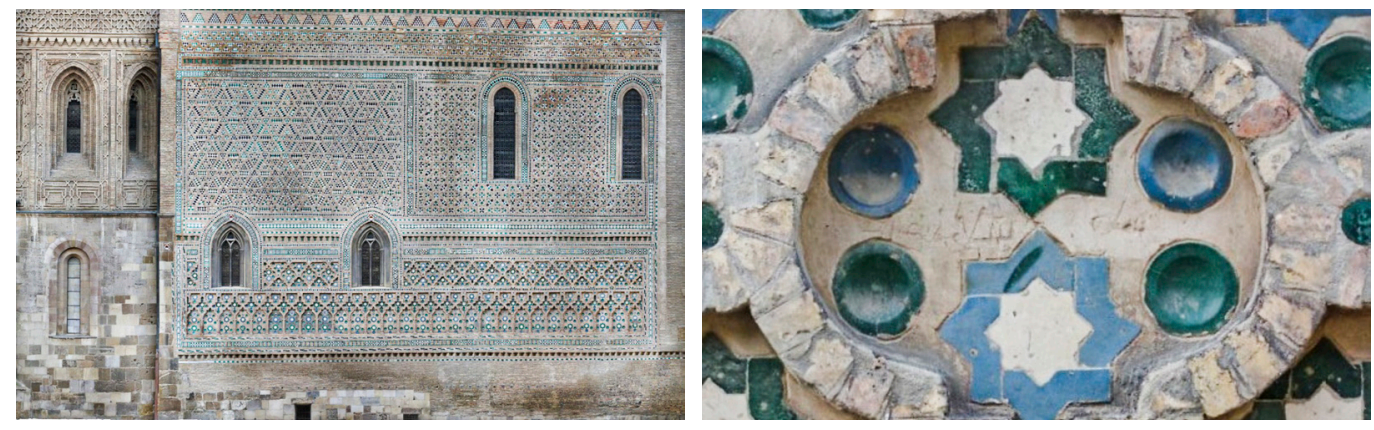

otros dos cuerpos el fondo está alicatado con azulejos blancos verdes y morados con diversos motivos geométricos. En el extremo izquierdo de la orla inferior se ha repuesto la inscripción que decía [González-Martí, Manuel 1952]:"AEDIFICATA: BENE: FUNDATA: EST: SUPRA: FIRMAM: PETRAM" edificada y bien fundada está, sobre piedra firme, mientras que

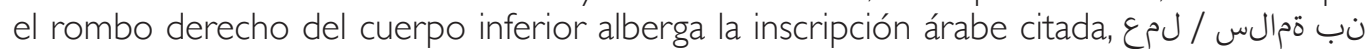
غاغ "la obra s de Salāma bn Gālib" (fig. 6).

El cuerpo inferior consta de dos bandas decorativas longitudinales que lo recorren entero, la inferior de arcos mixtilíneos entrecruzados, y la superior, más estrecha, es una sucesión de hexágonos curvilíneos apaisados entrecruzados, resultando rombos curvilíneos. El cuerpo central está dispuesto con dos grandes tableros decorados, rodeados por el mismo tipo de orla. El tablero de la derecha está totalmente decorado con lazo de ocho, "una estrella de ocho puntas, de ángulos rectos, que en las prolongaciones verticales y horizontales da lugar a la formación de un lazo de cuatro octogonal, encerrado en un cuadrado por las prolongaciones diagonales de la estrella de ocho. El tema se repite invariable hasta los límites de la composición" [Galiay Sarañana 2002]. El tablero izquierdo también está totalmente decorado, pero con lazo de 6. El cuerpo superior consta de dos partes, la inferior dispuesta con dos bandas de zigzag sobre fondo alicatado, y la superior con almenas triangulares, como las de Córdoba o Samarra. La segunda fachada del edificio, la recayente a la plaza, sigue en unos dos metros de longitud con la misma disposición decorativa, hasta que se le superpone una nueva fachada neoclásica que abarca no sólo la de la Parroquieta sino todo el frente del crucero hasta alcanzar el campanario, ya que constituye la fachada principal de la catedral.

\section{La composicion geométrica en la fachada norte de la Parroquieta}

Para le investigación y conocimiento geométrico del muro noreste, se procedió a la realización de una serie de vuelos con drone, que permitieran obtener datos fotográficos para poder realizar un levantamiento fotogramétrico, obteniendo 1236 fotografía del conjunto, de la cuales se ha realizado una selección de 648 para la obtención de la fachada noreste, debido a la repetición continua de geometrías colores y patrones de composición, ha sido necesario implementar gran cantidad de marcadores para correlacionar las fotografías con precisión, además del apoyo del geoposicionamiento de la cámara en el drone.

Para completar el levantamiento se ha realizado una campaña de toma de datos con escáner-laser, que fusionados con la nube de puntos procedente de la fotogrametría ha permitido obtener el modelo digital y de este la ortofotografia, que debidamente escalada ha proporcionado la base del lienzo de investigación.

La composición geométrica de la Parroquieta consiste en la superposición y entrecruzamiento de figuras geométricas simples -triángulos y cuadrados- combinadas para formar hexágonos, rombos, octógonos y estrellas de seis y ocho puntas. Abarca los tres cuerpos decorados, excepto la banda inferior del cuerpo bajo, dispuesta con arcos mixtilíneos entrecruzados. Mientras que los extensos paños decorados con las figuras geométricas $-y$ también las orlas que los delimitan y el cuerpo superior con las almenas- tienen los fondos 
Fig. 7. Levantamiento de la fachada noreste. Fuente autor.

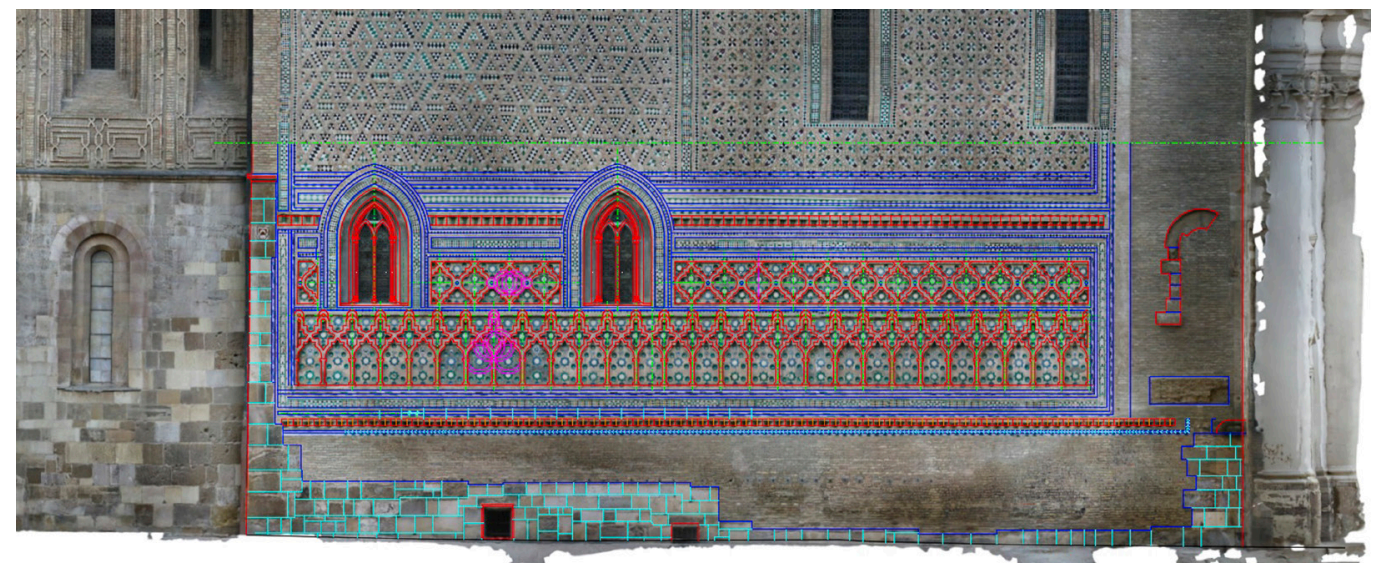

de los lazos totalmente recubiertos de azulejos, la banda de arcos entrecruzados y la inmediata superior de rombos limitan su decoración cerámica a incrustar azulejos de estrellas de ocho puntas y platos en un fondo de enlucido de yeso [ I] (fig. 7) No se conocen de forma documentada otros edificios como éste, ni en Aragón ni en el resto de España, salvo los ejemplos de las iglesias de la Virgen en Tobed y San Martín en Morata de Jiloca, ambas en la Comunidad de Calatayud. Los arcos entrecruzados tienen su antecedente en la ampliación de la mezquita de Córdoba, y el arco mixtilíneo en La Aljafería de Zaragoza ( I046- I08I), mientras que las figuras geométricas aparecen con los Abasíes y estilo Razi.

Del análisis, se ha observado que las dos ventanas góticas rompen la continuidad de la trama establecida, lo que induce a pensar que la fábrica de ladrillo y decorada con azulejo es anterior a las ventanas de piedra, también se observa que la irrupción de las ventanas no ha sido precisa, respetando los laterales de los huecos, sino que ha implicado la modificación de la fábrica de ladrillo y de los elementos ornamentales de cerámica vidriada (figg. 8, 9).

\section{Relación con otros edificios}

La arquitectura mudéjar, en Aragón presenta por igual labores decorativas geométricas de ladrillo con y sin cerámica vidriada, ésta presente principalmente en las torres. Estan documentados dos edificios cuya decoración parece estar estrechamente relacionada con la de la Parroquieta: La Aljafería de Zaragoza, y la techumbre de la sala capitular del monasterio de Sijena, en la comarca de Monegros, fatalmente incendiada a comienzos de la última guerra civil. El primero datado con fiabilidad durante el reinado de Ahmad I ( I046- I 08 I) y el segundo por conjeturas entre 1210 y 1223 [Cabañero Subiza 2000, pp. 32-34]. El re-

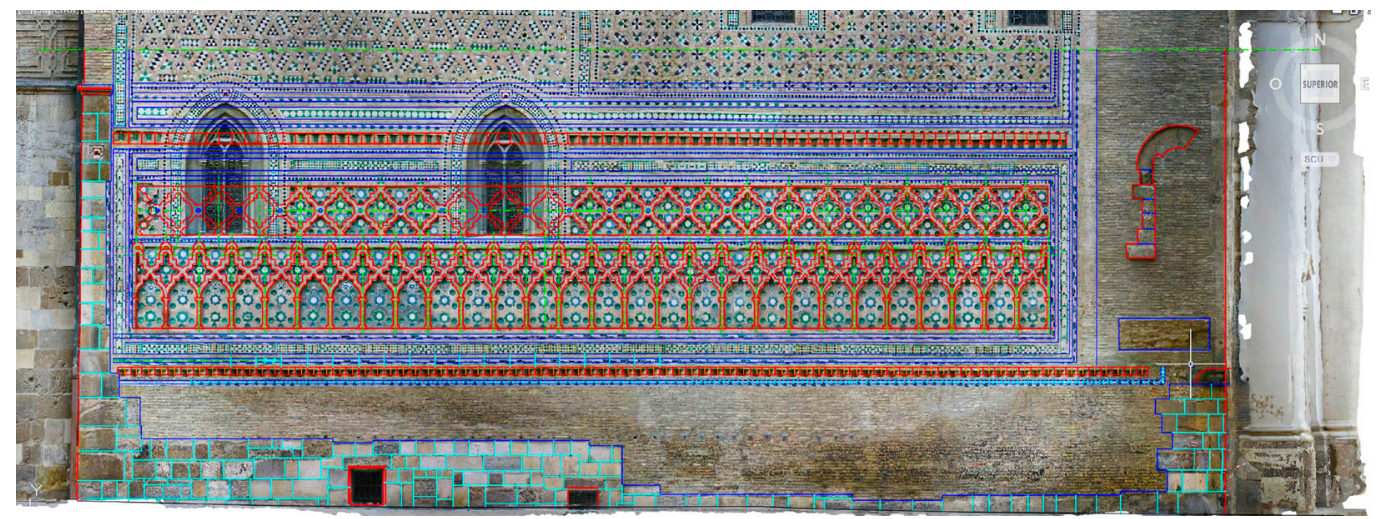


Fig. 9. Delineado de la composición. Fuente autor.

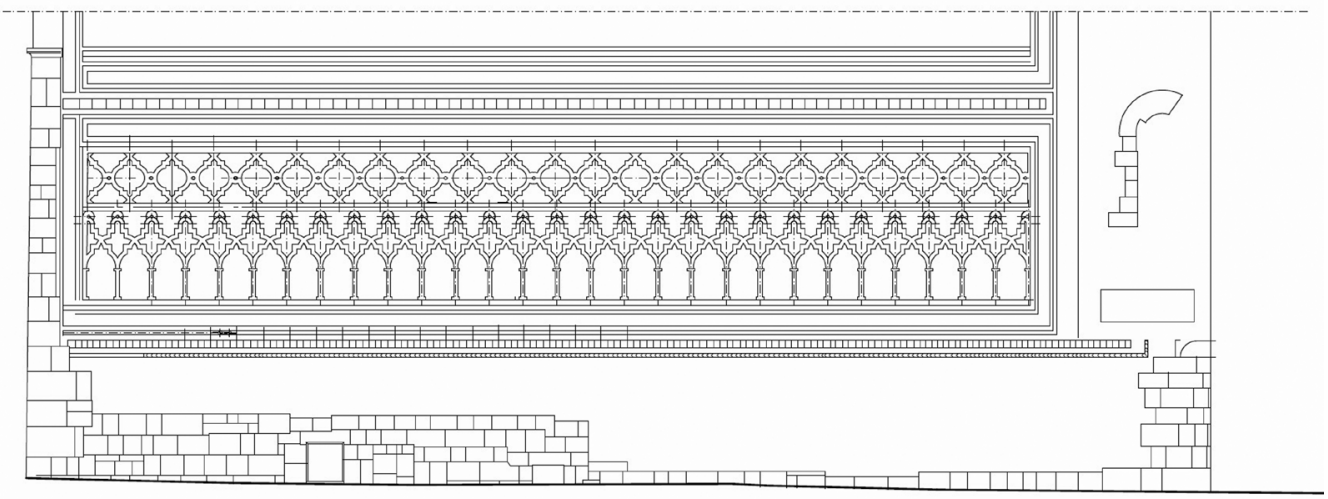

pertorio decorativo de La Aljafería incluye tanto el entrecruzamiento de arcos y el mismo tipo de complejo arco mixtilíneo, que aparecen en la banda inferior de la Parroquieta, como las figuras geométricas basadas en hexágonos, octógonos, y estrellas de seis y ocho puntas. La techumbre de la sala capitular de Sigena (fig. 10) constaba de 12 taujeles [2], todos ellos decorados a partir de hexágonos y octógonos que encierran estrellas de seis y ocho puntas, apoyados en jácenas con la misma decoración y en los arcos diafragma de piedra que soportan la techumbre de la sala y que estaban decorados con las pinturas murales normandas que hoy están en depósito en el MNAC.

\section{Conclusión}

Este paralelismo por la decoración geométrica en la arquitectura, entre Aragón y Oriente, y teniendo en cuenta que edificios como la Parroquieta, el palacio de la Aljafería o la techumbre de Sijena podrían llegar a datarse en torno al s. Xl, permite aventurar que a partir de los modelos de arquitectura Jorasaní y Razí, parten dos ramas, la Selyuquí en Oriente y otra desarrollada en Saraqusta en Occidente, que coinciden en el uso constructivo y decorativo del ladrillo y el yeso, pero que a partir de figuras geométricas simples inician dos vías de desarrollo independientes que, incomunicadas a partir de la conquista cristiana de Saraqusta, ésta evolucionará hacia la "arquitectura mudéjar", en la que la cerámica vidriada tiene un papel secundario y aquella hacia la "azerî" en la que los edificios llegan a estar totalmente cubiertos por la cerámica vidriada.

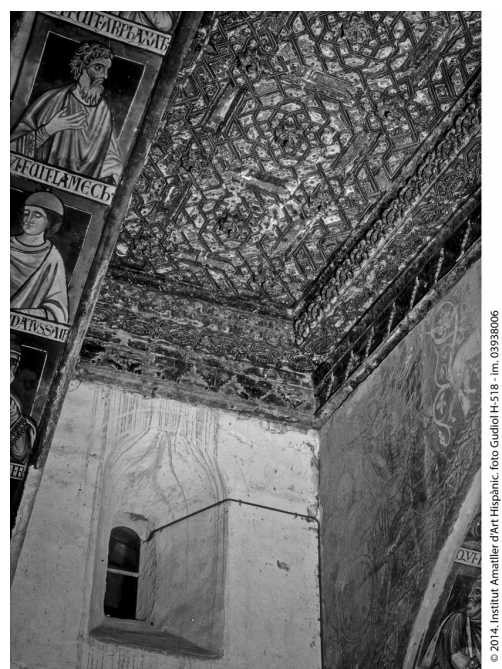




\section{Notas}

[I] Posiblemente, los fondos de yeso estuvieron policromados, como aún se conserva este tipo de decoración en la torre de Ateca (Comunidad de Calatayud).

[2] Taujel: o cinta. Listón o tablilla estrecha y alargada, decorada con gramiles o pintada, que se emplea en el revestimiento de una cubierta, especialmente si es islámica. Por extensión cualquier techumbre revestida de taujeles.

\section{Referencias}

Blair S., Bloom J. (2007). Asia central: timuríes, shaybaníes y principados de los kanes. Azulejos como decoración de edificios. In M. Hattstein, P. Delius (Eds.). Islam arte y arquitectura. Barcelona: H.F. Ullmann.

Cabañero Subiza B. (2000). La techumbre mudéjar de la Sala Capitular del monasterio de Sijena (Huesca): nuevos datos para el estudio de la evolución durante el siglo XII de los modelos de tableros geométricos de la Aljafería de Zaragoza. Publicación del Centro de Estudios Turiasonenses. Centro de Estudios Turiasonenses, Institución "Fernando el Católico", Diputación de Zaragoza, Tarazona.

Cabañero Subiza Bernabé B., Lasa Gracia C. (2004). Elementos arquitectónicos y decorativos nazaríes en el arte mudéjar aragonés, III: inscripciones de la Capilla de San Miguel de la Seo de Zaragoza. Artigrama. Departamento de Historia del Arte, Universidad de Zaragoza 19, pp. 337-360.

Chmelnizkij S. (2007). Los grandes Selyúcidas, los Selyúcidas de Anatolia y los shas de Jorezm. Arquitectura. In M. Hattstein, P. Delius (Eds.). Islam arte y arquitectura. Barcelona: H.F. Ullmann.

Enderlein V. (2007). Siria y Palestina: el califato de los Omeya. In M. Hattstein, P. Delius (Eds.). Islam arte y arquitectura. Barcelona: H.F. Ullmann.

Galiay Sarañana J. (2002). Arte Mudéjar aragonés. Zaragoza: Institución Fernando de Católico,.

González-Martí M. (1944). Cerámica del levante español: siglos medievales. 3, Azulejos, "Socarrats" y retablos. Barcelona: Labor.

Grabar O. (2007). Arte y cultura en el mundo islámico. La mezquita. In M. Hattstein, P. Delius (Eds.). Islam arte y arquitectura. Barcelona: H.F. Ullmann.

Martinez-Enamorado V. M., Peña-Gonzalvo J. (2016). La inscripción árabe de la parroquieta de Zaragoza y la mezquita aljama de Saraqusța. In Tudmir: Revista del Museo Santa Clara, n. 4, pp. I0 I- I I 3.

Pirnia M. (2003). Stylistics of architecture, dr. Gholamhossein Memarian (Ed.). Teherán: Pajhoohande (Memar) press.

Sanmiguel A. (2002). La cerámica en las restauraciones. In: J. Fermín, C. Mainar (coord.). Actas del X Coloquio de Arte Aragonés. Zaragoza, 9- I I mayo, 2002, pp. 247-264. Zaragoza: Institución Fernando el Católico.

\section{Autores}

Javier Peña Gonzalvo, Universidad de Zaragoza, jpenyagonzalvo@unizar.es

Luis Agustín Hernández, Universidad de Zaragoza, lagustin@unizar.es

Para citar este capitulo: Peña Gonzalvo Javier, Agustín Hernández Luis (202I). Analisis y composicion geometrica del frente norte de la capilla de San Miguel, la seo de Zaragoza/Analysis and geometric composition of the north front of the San Miguel chapel, the Seo of Zaragoza. In Arena A., Arena M. Mediati D. Raffa P. (a cura di). Connettere. Un disegno per annodare e tessere. Linguaggi Distanze Tecnologie. Atti del $42^{\circ}$ Convegno Internazionale dei Docenti delle Discipline della Rappresentazione/Connecting. Drawing for weaving relationship. Languages Distances Technologies. Proceedings of the $42^{\text {th }}$ International Conference of Representation Disciplines Teachers. Milano: FrancoAngeli, pp. 979-994. 


\title{
Analysis and Geometric Composition of the North Front of the San Miguel Chapel, the Seo of Zaragoza
}

\author{
Javier Peña Gonzalvo \\ Luis Agustín Hernández
}

Abstract

In the research work, in Architectural Heritage, using laser scanner technology and low-level terrestrial and aerial photogrammetry, has been done a digital surveying of the northeast façade of the chapel of San Miguel, known locally as la Parroquieta, to obtain an orthophotography and study the geometric decoration of said wall, which some authors describe as Mudejar, built by masters of Muslim origin who lived in Christian territory after the conquest of Saraqusta and others as Islamic architecture, where said wall would have belonged to the old aljama mosque of Saraqusta.

In the work, the current Chapel of San Miguel is described and it is related to the mosque, focusing the work on the northeast wall, making a detailed description of it making reference to the latest findings on inscriptions, a detailed geometric analysis, where it is concluded that the Gothic windows obey a different geometry from the geometric composition of ceramic and brick, and interrupt their modules and continuity, altering them.

It is also related to the decoration of the Islamic architecture of the East, essentially the Abbasid, since historical events relate both parts of the Caliphate to the split of Al-Andalus, to finally contextualize it with two nearby buildings in its environment, the Aljafería palace and the monastery of Sijena.

Keywords

geometric decoration, Zagrí architecture, Parroquieta, Saraqusta architecture.

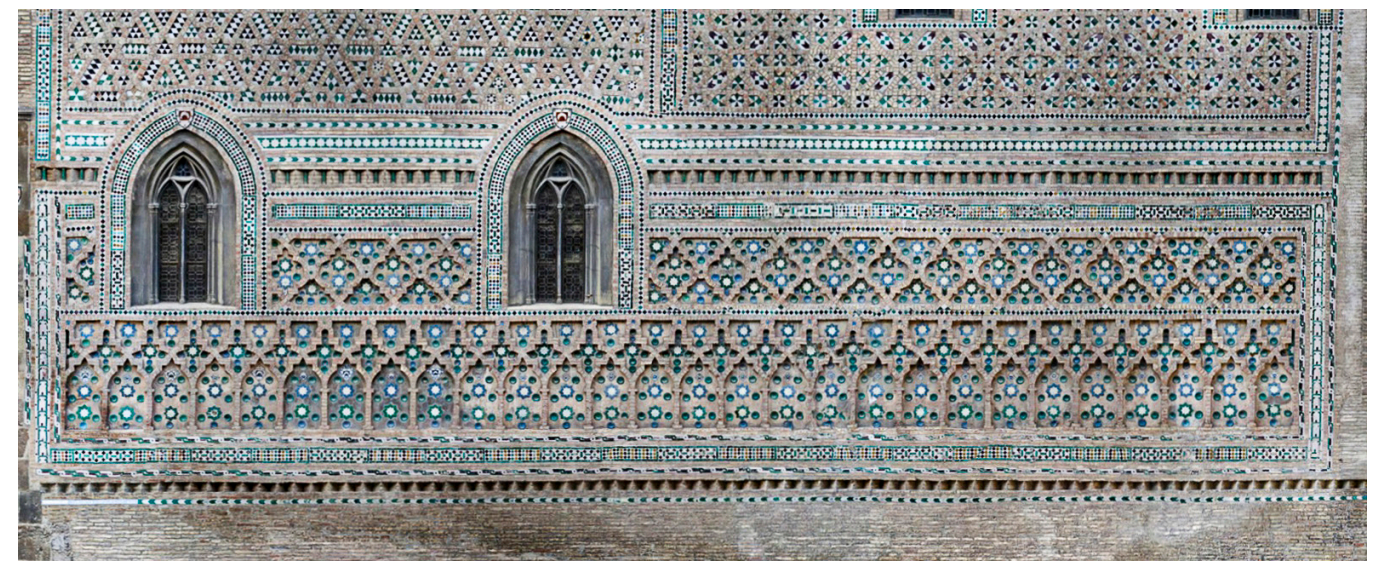




\section{Introduction}

La Parroquieta is the popular name for the Chapel of San Miguel, in the Cathedral of Zaragoza or Seo del Salvador, erected around 1380 by Archbishop Don Lop Ferrench de Luna to house his burial. La Seo was established in I 121, after the Aragonese conquest of Saraqusta, in the Aljama mosque, and it was not until the end of the XII century, when it begins its transformation by attaching three Romanesque apses that have survived to the present day, enabling a part of the extensive mosque for Christian use. In the XIV century continues the progressive replacement of the old Islamic building by a Gothic one, a church with three naves aligned with the apses. In the XVI century culminates its transformation, with its singular square plan, when it is extended in width and length to reach the old enclosures of the mosque, but still maintaining some of its elements, such as the new minaret wrapped in the baroque bell tower, or the NE wall possibly the wooden dome of the Parroquieta.

\section{Building}

It is a building attached to the SE to the apse of the Gospel, and to the SW to the nave of the transept, being exterior on the other two sides. With approximate dimensions of 22.50 $\times 10.00 \mathrm{~m}$ and a height of $17.00 \mathrm{~m}$ to the viewpoint that tops the building, it has a nave with two sections covered by ribbed vaults (figs. I, 2), worked in stone, something exceptional in the city of Zaragoza, and a presbytery with a square plan, covered by a wooden dome decorated with muqarnas and Arabic epigraphy; in an arcosolio the Gothic sarcophagus that contains the remains of the archbishop is located. The enclosures are double-paneled walls that house stairs and corridors, covered by brick brick vaults that in turn interlock the exterior with the interior, which avoids the construction of buttresses.

As in many other medieval buildings, the dating back to the XIX century de la Parroquieta has traditionally been carried out based on partial or circumstantial sources, in this case due to the specific intervention of a master builder, two sevillian tilemakers and a catalan sculptor, which cannot be conclusive. On the other hand, relevant aspects that may indicate the reuse of a previous building have not been taken into account, such as the violent irruption of the four Gothic windows in a façade equipped with an extensive and refined geometric decoration, the lack of structural and constructive harmony between the exterior, of brick

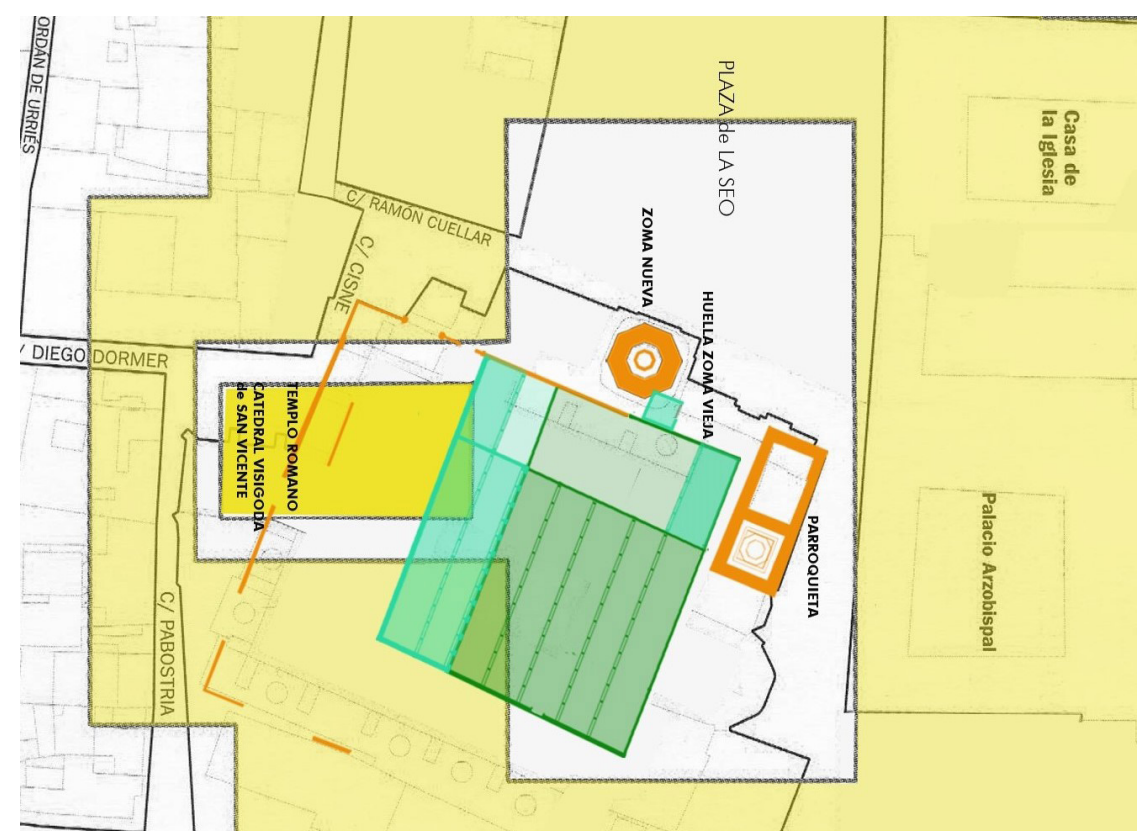


Fig. 2. Simulation of the Aljama Mosque of Saraqusta. Source Research Group in Architecture. Unizar. and the interior, of ashlar stone, and the unique decoration of the wooden dome of the presbytery, decorated with muqarnas and with "a very long inscription of complex Cufí writing, of about 40 linear meters" [Sanmiguel, Agustín 2002, p. 254], although other researchers relate it to Nasrid art (Cabañero Subiza, Bernabé, Lasa Gracia, Carmelo 2004). In 1992, a

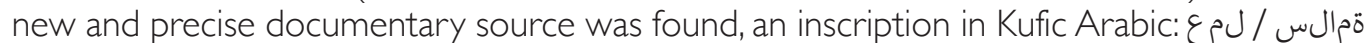
بل بلاغ نب "the work is by Salāma bn Gälib", dated to the s. XI [Martinez-Enamorado, PeñaGonzalvo 2016, p. II3].

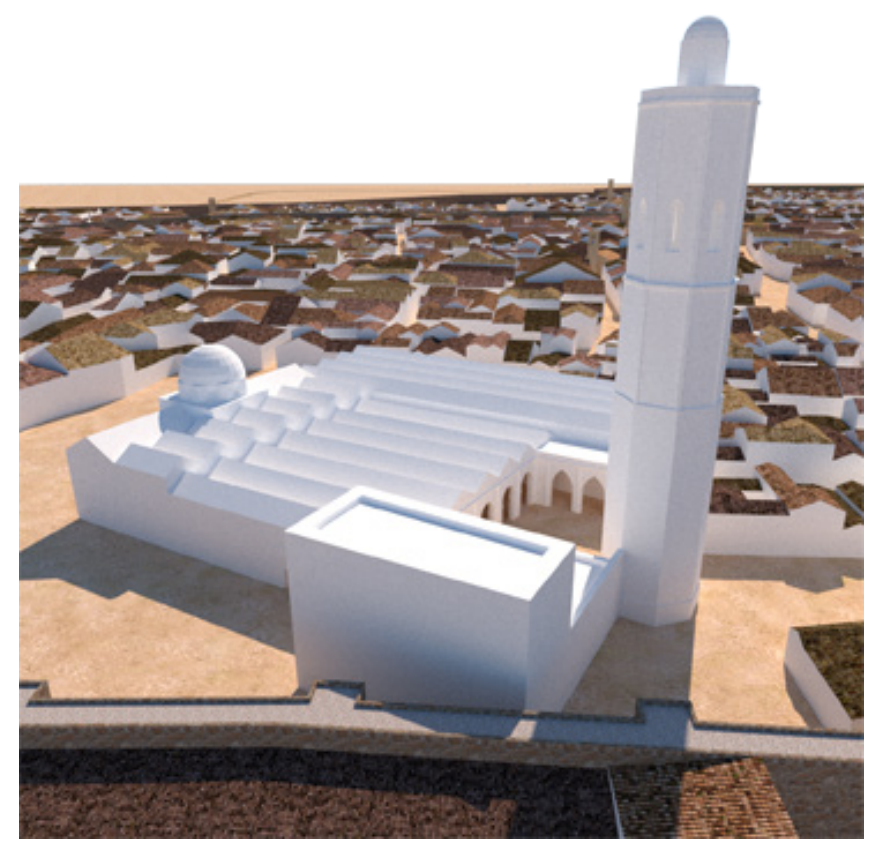

\section{The geometric decoration in islamic architecture}

The first Islamic architecture, that of the Umayyad period, represented by the mosques of the Dome of the Rock in Jerusalem (69I-692) and the Aljama mosque in Damascus (706-7|4), "corresponds in all its details to the common forms of Christian art in Syria and Palestine" [Enderlein 2007, p. 65). In 749, the Abbasids seize power from the Umayyads, moving their residence to Iraq and in 762 al-Mansur builds the new capital, Baghdad, in a geographical environment where brick and stucco were settled before Islam, so it was adopted. The decoration with geometric figures already appears in the castle of Uxaydir (775) and combined with vegetal decoration it is conserved in the oldest buildings of Samarra, the new Abbasid capital between 835 and 892. The geometric order became the norm of art Islamic, who wanted to avoid images, but nevertheless wanted to satisfy the needs of all cultures to be able to repeat their best creations" [Grabar 2007, p. 49].

In NE Iran, after the coming to power of local dynasties, the oldest preserved examples appear, where brick and plaster allow geometry to be the main decorative support. According to the characterization of the Islamic Iranian architectural styles until the XIII century (Pirnia 2003), the Khorasaní style is the first to appear, highly influenced by pre-Islamic architecture, such as the Na'in Mosque, s. X. The second style is the Razí, which includes three branches, the Samaní, with the mausoleum of Isma'il (892-907), Bujará (fig. 3); the Ziyarí, with the tower-mausoleum of Gonbad-e Kavus ( 1006-1007), or the doorway of the Jurjir mosque (976-985) in Isfahan; and the Selyuquí, which since the middle of the XI century, masterfully employs brick arranged with more complex geometric laceries: "The brick, usually square and combined in different ways ... was used both for construction and for decoration ... with different colored earthenware -turquoise bands, ornamental stones of dark blue, 
Fig. 3. Ismail Samani Mausoleum. Go down to. Source: copyright free internet.

Fig. 4. Aljafería Palace. Zaragoza. Source Photograph of the author
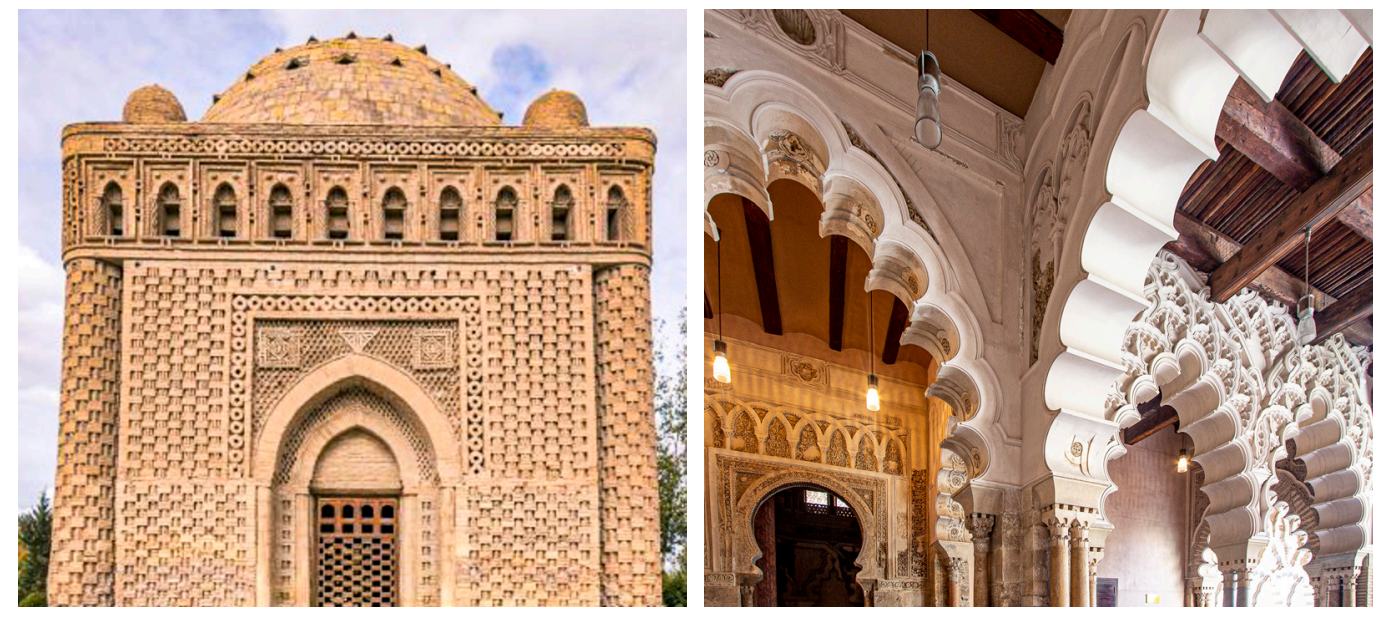

white and green, enriched the ocher of the building-" [Chmelnizkij 2007, p. 354]. Mosques, minarets, mausoleums, caravanserai and all kinds of public buildings, present geometric decorative solutions, such as six-pointed, eight-pointed stars, linked or not, rhombuses, chains, crosses, etc. many of them also present in Aragonese Mudejar architecture.

About glazed pottery, "the use of tiles began in Islamic art in the 9th century, these luster tiles (from Kairouan), adorned in different shades of green, brown and yellow, were probably imported from Iraq ... (arranged) in a rhomboid pattern to fold the decorated surface. At the end of the II th century, the technique of joining tiles was developed in North Africa, turning them into a geometric pattern ... in the second half of the I2th century, bands and panels of tiles were used to adorn the Almohad minarets of Morocco and Andalusia. In the eastern Islamic countries, the use of tile decoration took another direction from the I I th century ... they began to experiment with glazed elements of turquoise color, but soon other colors were added such as white and cobalt blue and the surfaces decorated with tiles were gaining size" (Blair et al. 2007, p. 448).

The strong personality of the Abbasid culture was also noted in Al-Andalus, and thus, the extension of Alhaquén II of the Cordoba mosque (962-966) incorporates elements of that, especially the geometry in the decoration in the ribbed vaults located in the maqsura and in the enlarged central nave, which also incorporate lobed and criss-crossed arches. These elements are also preserved in the small mosque of Bib Mardúm, Toledo (999/ / 000). The palace of the Aljafería de Zaragoza, second half of the XI century, will develop these geometric elements and incorporate new ones such as the mixtilinear arches (fig. 4).

\section{The northeast wall}

The large rectangular panel that occupies most of the NE façade (fig. 5) consists of three parts separated by two bands of corners, the central one and the upper one decorated with green glazed columns, and in turn, each one of them, framed with a narrow border decorated with arrowhead tiles, generally white and green, and other wider ones decorated with glazed ceramic of small square (in lozenge) and rectangular tiles of honey, white, green and purple-blackish colors. While the lower part has its recessed and plastered interior, decorated with tiles of three types: 8-pointed white stars edged with green or blue tiles, green ceramic plates and white tiles arranged in a lozenge with the arms of the Ferrench de Luna, in the other two parts, the background is tiled with white, green and purple tiles with various geometric motifs. At the extreme left of the lower border the inscription has been replaced that said (González-Martí, Manuel 1952): "AEDIFICATA: BENE: FUNDATA: EST: SUPRA: FIRMAM: PETRAM" built and well founded is, on firm stone, while the right rhombus of the lower part has the aforementioned Arabic inscription, بل "the works of Salāma bn Gālib" (fig. 6). 
Fig. 5. Northeast wall orthophotography

Authors' research source.

Fig. 6. Detail where the aforementioned inscription is observed. Source image of the author.
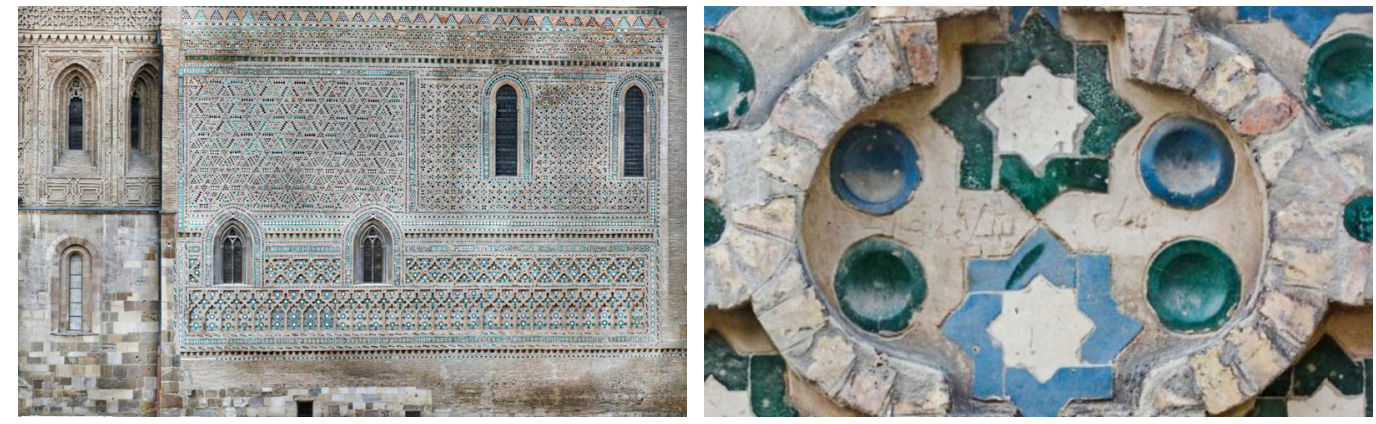

The lower part consists of two longitudinal decorative bands that run through it, the lower one of interlocking mixtilinear arches, and the upper one, narrower, is a succession of interlocking horizontal curvilinear hexagons, resulting in curvilinear rhombuses. The central part is arranged with two large, decorated boards, surrounded by the same type of border. The panel on the right is fully decorated with a loop of eight, "an eight-pointed star, with right angles, which in the vertical and horizontal extensions gives rise to the formation of a four-octagonal loop, enclosed in a square by the extensions. diagonals of the eight stars. The theme is invariably repeated up to the limits of the composition" (Galiay Sarañana 2002). The left panel is also fully decorated, but with a loop of 6. The upper part consists of two parts, the lower part arranged with two zigzag bands on a tiled background, and the upper part with triangular battlements, such as those of Córdoba or Samarra. The second façade of the building, the one that leads to the square, continues for about two meters in length with the same decorative arrangement, until a new neoclassical façade is superimposed that covers not only that of the Parroquieta but the entire front of the transept until reaching the bell tower, since it constitutes the main facade of the cathedral.

\section{The geometric composition in the north facade of the Parroquieta}

For the investigation and geometric knowledge of the northeast wall, a series of drone flights were carried out, which allowed obtaining photographic data to be able to carry out a photogrammetric survey, obtaining 1236 photographs of the whole, from which a selection of 648 to obtain the northeast façade, due to the continuous repetition of colored geometries and composition patterns, it has been necessary to implement a large number of markers to accurately correlate the photographs, in addition to supporting the geopositioning of the camera on the drone.

To complete the survey, a data collection campaign has been carried out with a laser scanner, which, when merged with the point cloud from photogrammetry, has allowed the digital model to be obtained and from this the orthophotography, which has been duly scaled and provided the base of the canvas research.

The geometric composition of the Parroquieta consists of the superposition and interweaving of simple geometric figures -triangles and squares-combined to form hexagons, rhombuses, octagons, and six and eight-pointed stars. It covers the three decorated parts, except for the lower band of the lower part, arranged with interlocking mixtilinear arches. While the extensive panels decorated with geometric figures and also the borders that delimit them and the upper part with battlements- have the bottoms of the loops completely covered with tiles, the band of interlocking arches and the immediate upper one with diamonds limit their ceramic decoration to be embedded eight-pointed star tiles and plates in a plaster background (fig. 7). Other buildings like this are not known in a documented way, neither in Aragon nor in the rest of Spain, except for the examples of the churches of the Virgin in Tobed and San Martín in Morata de Jiloca, both in the Community of Calatayud. The interlocking arches have their antecedent in the enlargement of the mosque in Córd- 


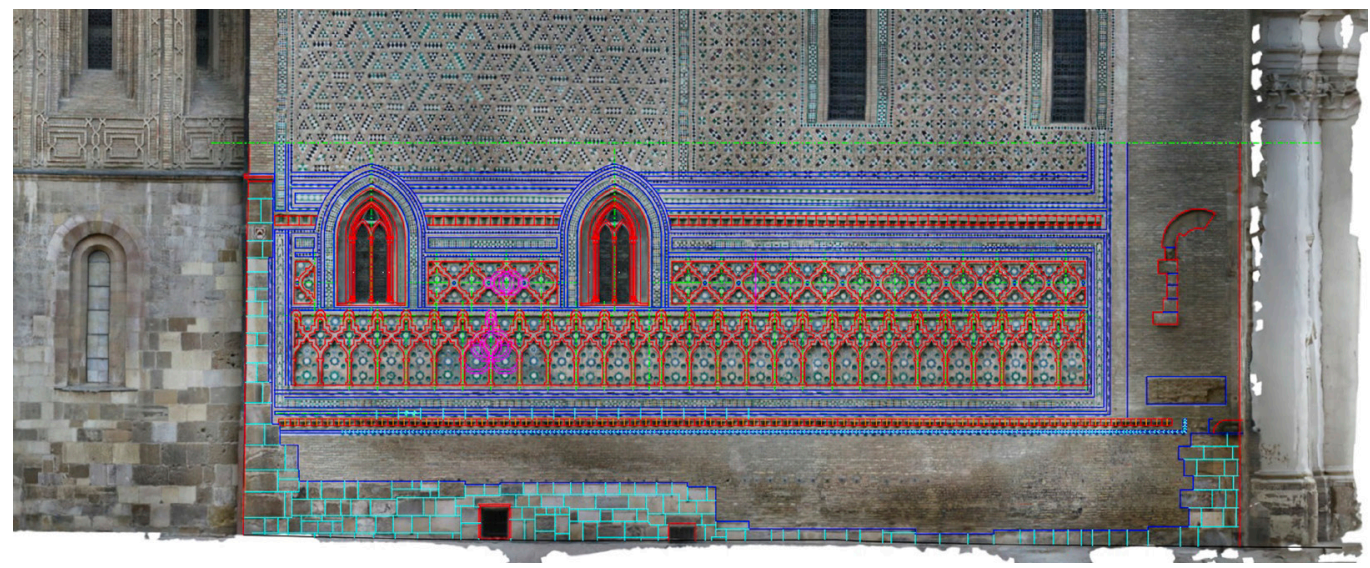

oba, and the mixtilinear arch in La Aljafería de Zaragoza (I046- I08 I), while the geometric figures appear in the Abbasid and Razi style.

From the analysis, it has been observed that the two Gothic windows break the continuity of the established plot, which leads us to think that the brick factory and decorated with tiles predates the stone windows, it is also observed that the irruption of the windows It has not been precise, respecting the sides of the holes, but has implied the modification of the brickwork and the ornamental glazed ceramic elements (figs. 8, 9).

\section{Relationship with other buildings}

Mudejar architecture, in Aragon, presents geometric decorative brickwork with and without glazed ceramics, this one present mainly in the towers. Two buildings whose decoration seems to be closely related to that of the Parroquieta are documented: La Aljafería in Zaragoza, and the roof of the chapter house of the Sijena monastery, in the Monegros region, fatally burned at the beginning of the last civil war. The first dated reliably during the reign of Ahmad I (I046-I08I) and the second by conjecture between I IIO and I223 [Cabañero Subiza 2000, pp. 32-34]. The decorative repertoire of La Aljafería includes both the interweaving of arches and the same type of complex mixtilinear arch, which appear in the lower band of the Parroquieta, as well as geometric figures based on hexagons, octagons, and six and eight-pointed stars.

The roof of the Sigena chapter house (fig. I 0 ) consisted of 12 taujeles, all of them decorated from hexagons and octagons that enclose six and eight-pointed stars, supported by girders with the same decoration and by stone diaphragm arches. that support the ceiling of the room and that were decorated with the Norman wall paintings that today are on deposit at the MNAC.

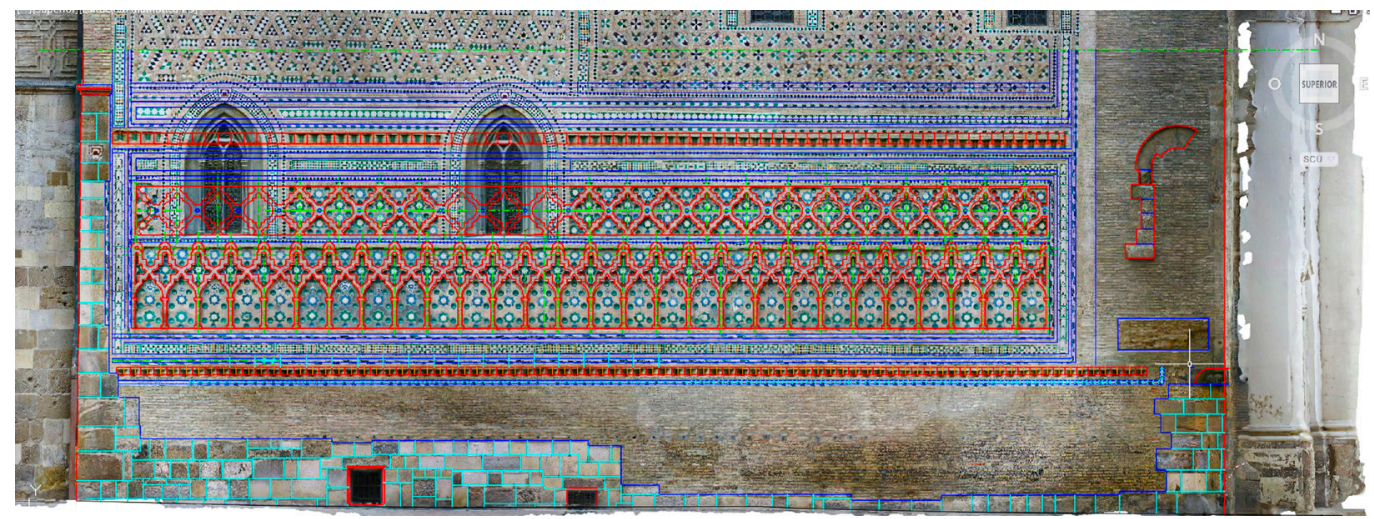




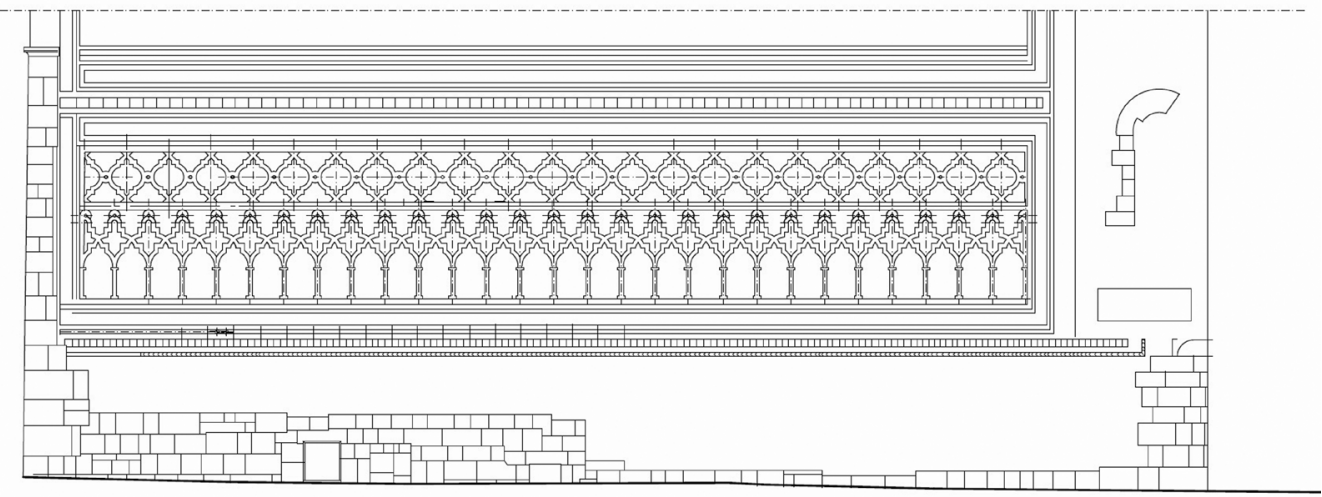

\section{Conclusions}

This parallelism due to the geometric decoration in the architecture, between Aragón and Oriente, and taking into account that buildings such as the Parroquieta, the Aljafería palace or the roof of Sijena could date around the s. Xl, allows to venture that from the Jorasaní and Razí architecture models, two branches start, the Selyuquí in the East and another developed in Saraqusta in the West, which coincide in the constructive and decorative use of brick and plaster, but that from Simple geometric figures initiate two independent development paths that, cut off from the Christian conquest of Saraqusta, this one will evolve towards Mudejar architecture, in which glazed ceramics have a secondary role and that towards Azeri in the that the buildings become totally covered by glazed ceramics.

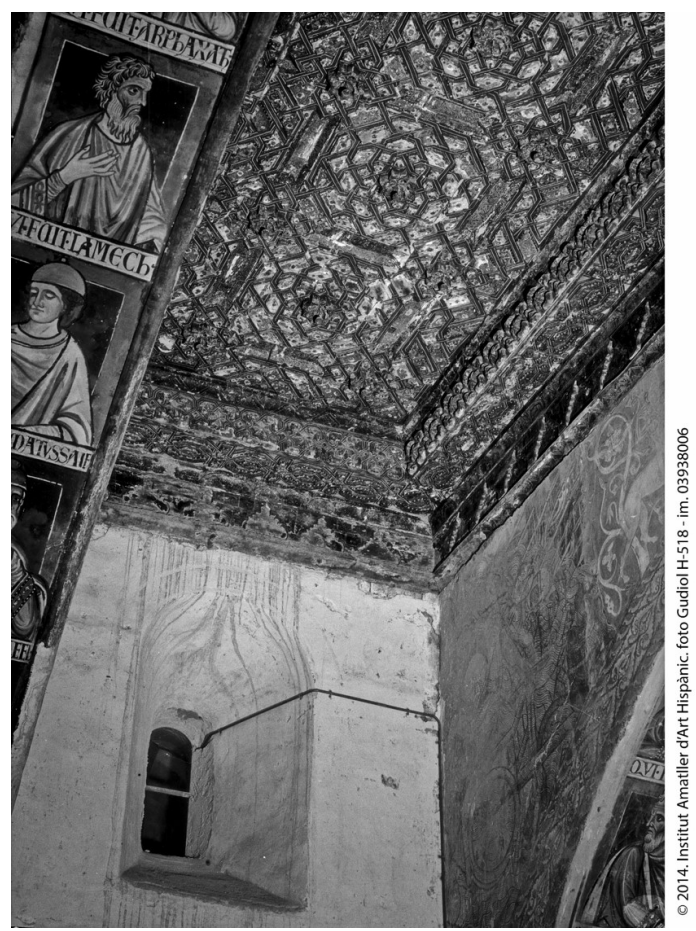




\section{References}

Blair S., Bloom J. (2007). Asia central: timuríes, shaybaníes y principados de los kanes. Azulejos como decoración de edificios. In M. Hattstein, P. Delius (Eds.). Islam arte y arquitectura. Barcelona: H.F. Ullmann.

Cabañero Subiza B. (2000). La techumbre mudéjar de la Sala Capitular del monasterio de Sijena (Huesca): nuevos datos para el estudio de la evolución durante el siglo XII de los modelos de tableros geométricos de la Aljafería de Zaragoza. Publicación del Centro de Estudios Turiasonenses. Centro de Estudios Turiasonenses, Institución "Fernando el Católico", Diputación de Zaragoza, Tarazona.

Cabañero Subiza Bernabé B., Lasa Gracia C. (2004). Elementos arquitectónicos y decorativos nazaríes en el arte mudéjar aragonés III: inscripciones de la Capilla de San Miguel de la Seo de Zaragoza. Artigrama. Departamento de Historia del Arte, Universidad de Zaragoza 19, pp. 337-360.

Chmelnizkij S. (2007). Los grandes Selyúcidas, los Selyúcidas de Anatolia y los shas de Jorezm. Arquitectura. In M. Hattstein, P. Delius (Eds.). Islam arte y arquitectura. Barcelona: H.F. Ullmann.

Enderlein V. (2007). Siria y Palestina: el califato de los Omeya. In M. Hattstein, P. Delius (Eds.). Islam arte y arquitectura. Barcelona: H.F. Ullmann.

Galiay Sarañana J. (2002). Arte Mudéjar aragonés. Zaragoza: Institución Fernando de Católico,.

González-Martí M. (1944). Cerámica del levante español: siglos medievales. 3, Azulejos, "Socarrats" y retablos. Barcelona: Labor.

Grabar O. (2007). Arte y cultura en el mundo islámico. La mezquita. In M. Hattstein, P. Delius (Eds.). Islam arte y arquitectura. Barcelona: H.F. Ullmann.

Martinez-Enamorado V. M., Peña-Gonzalvo J. (20 I6). La inscripción árabe de la parroquieta de Zaragoza y la mezquita aljama de Saraqusța. In Tudmir: Revista del Museo Santa Clara, n. 4, pp. I0 I - I 3.

Pirnia M. (2003). Stylistics of architecture, dr. Gholamhossein Memarian (Ed.). Teherán: Pajhoohande (Memar) press.

Sanmiguel A. (2002). La cerámica en las restauraciones. In: J. Fermín, C. Mainar (coord.). Actas del X Coloquio de Arte Aragonés. Zaragoza, 9- I I mayo, 2002, pp. 247-264. Zaragoza: Institución Fernando el Católico.

\section{Authors}

Javier Peña Gonzalvo, Universidad de Zaragoza, jpenyagonzalvo@unizar.es

Luis Agustín Hernández, Universidad de Zaragoza, lagustin@unizar:es

To cite this chapter. Peña Gonzalvo Javier, Agustín Hernández Luis (202I). Analisis y composicion geometrica del frente norte de la capilla de San Miguel, la seo de Zaragoza/Analysis and geometric composition of the north front of the San Miguel chapel, the Seo of Zaragoza. In Arena A., Arena M. Mediati D. Raffa P. (a cura di). Connettere. Un disegno per annodare e tessere Linguaggi Distanze Tecnologie. Atti del $42^{\circ}$ Convegno Internazionale dei Docenti delle Discipline della Rappresentazione/Connecting. Drawing for weaving relationship. Languages Distances Technologies. Proceedings of the $42^{\text {th }}$ International Conference of Representation Disciplines Teachers. Milano: FrancoAngeli, pp. 979-994. 